\title{
Factoring Size into the Equation Media studies, politics, and small states
}

\author{
Jón Gunnar Ólafsson
}

Goldsmiths, University of London, UK

\begin{abstract}
In this article, I discuss how the world's smallest states, including Iceland, are routinely absent in research and comparative studies concerning media and politics. Size has up until now mostly been ignored as a possible factor in understanding media systems and the relationship between media and politics on the national level. Existing research from other academic fields, such as public administration and economics, has revealed an important finding: small states have unique characteristics that differentiate them from larger states. They can therefore not simply be viewed as smaller versions of large states that have been central in knowledge production. Arguably, a Nordic perspective in media research needs to incorporate the size variable into the research agenda. This article illustrates how this expanded agenda will enrich our understanding of media and politics in the Nordic countries and open up new areas of study on small and large states more generally.
\end{abstract}

Keywords: Small states, Iceland, media, politics, political communication

\section{Introduction}

One of the challenges concerning research on the "Nordic media system" is that the diversity of the Nordic region is often overlooked when scholars attempt to describe what the countries in the region have in common in relation to their media environment. One frequent area of exclusion in the literature on media and communication in the Nordic countries is research from Iceland - a country that is routinely absent from comparative studies. Despite this, it is often mentioned alongside the other four, much larger, Nordic countries and defined as some sort of "Nordic model" (Jóhannsdóttir \& Ólafsson, 2018). This is not without its problems. One key area of difference between Iceland and the other Nordic states concerns population size. Currently, there are around 360,000 people living in Iceland (Statistics Iceland, 2020), whilst Norway, the second least populated Nordic country, has over 5 million inhabitants. Sweden, the most populated Nordic

Ólafsson, J. G. (2020). Factoring size into the equation: Media studies, politics, and small states. Nordic Journal of Media Studies, 2, 145-156. https://www.doi.org/10.2478/njms-2020-0013 
country, has over 10 million inhabitants, or roughly 30 times the population of Iceland (Central Intelligence Agency, 2020).

Size has, up until now, mostly been ignored as a possible factor in understanding media systems and the relationship between media and politics on the national level. Arguably, a Nordic perspective in media research needs to incorporate the size variable into the research agenda if the aim is to understand all countries in the region. I begin this article by discussing how the size variable has up until now mostly been used to understand structural elements. I then trace different ways that small states have been defined in international relations and economics before proposing that we need to expand this examination to include a definition concerning socio-cultural aspects. This highlights possible differences between Iceland and the other Nordic countries that are worthy of exploration in future studies.

\section{Small states and media systems}

It quickly becomes apparent when examining comparative work on media and politics that the small states of the world are routinely overlooked, as is the question of size as a variable in the relationship between media and politics on the national level (e.g., Albæk et al., 2014; Dobek-Ostrowska et al., 2010; Van Dalen \& Van Aelst, 2014). In an attempt to add small states to the comparative debate, a 2009 issue of The International Communication Gazette was devoted entirely to media systems in small states. In the introduction, Puppis (2009) points out that small states have mostly been absent from the media systems research agenda and mentions that Hallin and Mancini's (2004) typology neglects the size of media systems. He claims that the small state perspective is important for analysing media systems, since small states share structural peculiarities that have implications for their media landscapes.

Puppis argues that it is possible to distinguish between small states and microstates with a few thousand inhabitants, but that it is more difficult to decide on the upper limit. Following this, Puppis states: "For Europe, usually all countries aside from France, Germany, Italy, Poland, Romania, Spain and the UK are considered small states". He subsequently goes on to define small states as "countries with a minimum of 100,000 and a maximum of 18 million inhabitants. This range allows for the inclusion of the Netherlands - admittedly a giant among the small ones" (Puppis, 2009: 8). The special issue includes discussions on Denmark, Sweden, Norway, Estonia, Lithuania, Latvia, Belgium, Switzerland, Austria, and Portugal. These states are often classified as small states in the international relations literature (as will be explained in the following section) but noticeably absent are states with less than 1 million inhabitants like Iceland, Malta, or Luxembourg. Puppis's attempt to bring the small state perspective to the comparative media systems field is an important development since he emphasises how various research agendas have been blind when it comes to the size of states. ${ }^{1}$ However, 
his definition is not without problems. Where one places the population limit is always arbitrary, but what the subsequent discussion on the social ecology of small states illustrates is that smaller states differ somewhat from the "small states" with larger populations, like Sweden and Belgium. A noticeable research gap still exists in the media systems literature when many states classified as small (according to Puppis's definition) were, in fact, originally included in Hallin and Mancini's work - but smaller states excluded from Hallin and Mancini's work are also excluded from the special issue, as well as from most comparative research in political communication.

Puppis (2009) argues that the economic realities of small states are of importance and have implications for their media systems. He claims that small media systems share four structural peculiarities. First, with regard to shortage of resources, it is clear that small states face various limitations on the production side. Second, small audience and advertising markets mean that, even though the production costs can be the same, the audience market is very small and there are limits to advertising revenues. Third, Puppis argues that dependence is an important factor; small media systems are strongly affected by developments such as globalisation and commercialisation but are less able than larger states to influence this. Finally, small media systems are particularly vulnerable when it comes to foreign takeovers (Puppis, 2009: 10-11).

There are some fundamental differences regarding these peculiarities when one compares the Icelandic system, with roughly 360,000 inhabitants, and the much larger "small states". These differences are not addressed in the existing work on media systems. I argue that the question of resource constraints needs to be expanded from being mainly used to explain structural peculiarities of the system to also include socio-cultural factors, as examined below. Uncovering these socio-cultural aspects requires a different type of definition than the one introduced by Puppis.

If the definition of 100 thousand-18 million inhabitants is seen as limited, then what is a more useful definition? Exploring the literature in comparative politics - where much effort is put into researching and defining different types of states - leaves one without clear answers. Even though the comparative approach is much more established in political science than in media studies and political communication (de Vreese, 2017), the smallest countries are likewise largely excluded. As Veenendaal and Corbett (2015) emphasise, although there are significant differences in the threshold that researchers apply in order to exclude small states, it is striking that almost all publications employ a cut-off point resulting in the elimination of these states. Many scholars do not even provide a substantive justification for their decision to omit small states: "The assumption is implicit: Small states do not matter" (Veenendaal \& Corbett, 2015: 528).

Veenendaal and Corbett (2015) argue that small states do indeed matter. First, if small states are similar to larger states regarding political arrangements, then researchers waste valuable data by not including them: 
To omit states with less than 500,000 inhabitants would now mean that approximately $15 \%$ of the available cases are excluded from analysis. This figure grows to more than $20 \%$ if the population threshold is raised to 1 million. (Veenendaal \& Corbett, 2015: 529)

Second, if small states differ from larger states politically, then we miss out on the insights these diverse, extreme, or most different cases offer. The focus here highlights the latter, and in order to understand these differences, there is a need to engage with research from another academic field.

\section{International relations, economics, and small state studies}

There is a growing body of research that can be labelled small state studies (Randma-Liiv \& Sarapuu, 2019). This research can be divided into two research streams. First, there is the emphasis on exploring small states with regard to economics and international relations (e.g., Ingebritsen et al., 2006). This usually addresses the role of small states in the global arena, as opposed to studying domestic governance issues (Randma-Liiv \& Sarapuu, 2019). Second, there is research on internal governance aspects, such as distinct public administration characteristics or domestic politics (e.g., Corbett \& Veenendaal, 2018; Randma, 2001).

These two streams rely on very different definitions. The interest of those focusing on small states in global economics and international relations is mainly on small states as "small powers". As Sarapuu (2010) argues, the focus on small powers allows for a flexible approach to the countries being studied, making "small" dependent on other parts of the comparison. This approach is largely shared by economists and places the small states in the external environment since it defines small states vis-à-vis their external relations (Randma-Liiv \& Sarapuu, 2019).

The limits of these types of flexible relational definitions is that they mainly illustrate how small states compare to larger states and do not focus on the internal governance aspects of small states. These definitions are therefore not particularly helpful starting points for media and politics research aiming to understand what takes place within particular small states or media systems. Importantly, these definitions are also too wide and, as a result, fail to hone in on what makes the smallest states different from the larger "small states".

The second stream focuses more on the internal governance aspects of small states. In this stream, one finds much more emphasis placed on finding an absolute criterion for defining "small”. By far the most widespread criteria used is that of the state's population (e.g., Randma-Liiv, 2002). However, the population figures used differ drastically from the wide definition introduced earlier in relation to media systems (Puppis's definition of 100 thousand-18 million), and in the international relations literature, where common cut-off points are 10,15 , or even 30 million inhabitants (Thorhallsson \& Steinsson, 2017). 
Within the internal governance research stream, small states have commonly been defined as those states with a population of 1 million or less (e.g., Corbett \& Veenendaal, 2018). It is striking how this research stream drastically differs from the international relations research stream and the definition presented by Puppis (2009). Norway, Finland, Denmark, and Sweden are usually considered small states in the international relations and European Union context, but they are too populous to be considered "small" in the internal governance research stream. The only sovereign Nordic country that would be defined as small using the population definition within the second stream is Iceland.

\section{Five traits of small states and a unique social ecology}

A narrower definition concerning population size than found in the international relations, economics, and media systems literature is necessary in order to comprehend the uniqueness of the internal workings of very small states - this is based on previous research on small states. As Sarapuu (2010: 33) sums up, small states have been shown to have special characteristics and particular behavioural "patterns the more one goes down the scale (size of population being the criterion)". Research shows that population influences the inner workings of small states mainly through two mechanisms: first, through the limited availability of resources, mostly human capital; and second, through a particular type of social ecology. The argument is not to adopt a particular cut-off point regarding population size. Instead, there is evidence for a continuum of size, in which these mechanisms become more apparent the smaller the population becomes, regardless of other traits in the state (Bray \& Packer, 2006; Sarapuu, 2010; Randma-Liiv \& Sarapuu, 2019).

In her review of existing studies, Sarapuu (2010) defines five traits of small states: 1) limited scope of activity; 2) multi-functionalism; 3) reliance on informal structures; 4) constraints on steering and control; and, finally, 5) higher personalism. Sarapuu focuses specifically on public administration, but the research on small states can be applied to other areas, such as the relationship between media and politics. These five traits highlight various socio-cultural differences between smaller and larger states. This is a key difference from the media systems literature, since the focus is not mainly on structural peculiarities.

With regard to the first trait of small states, it has been shown that the burden of statehood is much higher for small states than larger ones. There are certain functions that states must fulfil regardless of their size, and there is greater need to prioritise scant resources (Randma-Liiv \& Sarapuu, 2019). The second trait is multi-functionalism. The small size of states limits specialisation, and it is common for senior officials in small states to be responsible for several sectors, which in larger countries are catered to by separate units (Farrugia, 1993). Small states tend to have more multifunctional ministries, and there is often no clear-cut division between policy formation and implementation (Sarapuu, 2010). Linked to 
the limited scope of activity and multi-functionalism is the third trait - reliance on informal structures. Small state administrations tend to rely more on flexibility, and the interaction between units is often characterised by a lack of machinery for formal coordination and heavier reliance on informal means of communications (Raadschelders, 1992). The tendency of small states seems to be to adapt structures and jobs to people, rather than to fit individuals into formal organisational frameworks (Randma, 2001).

The fourth trait focuses on constraints on steering and control. It emphasises that the institutionalisation of control mechanisms demands resources prescribed for that task as well as specific expert knowledge. Small states tend to be constrained in both. When many intervening management levels are missing, problematic issues will quickly reach the top of the administration: "Therefore, there is an incentive built into the small systems to trust the competence of individual officials and units" (Sarapuu, 2010: 37). Finally, regarding the fifth trait, higher personalism, it has been shown that small states are characterised by a high degree of interpersonal relations. As Farrugia (1993) illustrates, states with a small number of inhabitants tend to develop closely integrated societies containing an intricate network of personal relationships. People know each other (or know someone who knows someone whose service they need), so ministers, parliamentarians, journalists, and others are easily reachable. As he states, "it is not unusual in these circumstances for people who cannot obtain formal appointments to manage to get invited to social functions or family reunions where they can casually meet the minister or official concerned" (Farrugia, 1993: 222).

In sum, the wide relational definitions are problematic starting points in media and politics research since they end up grouping together the smallest states and "small states" like Sweden and the Netherlands. Research shows that when focusing on the internal aspects of small states, it is more useful to adopt a continuum of size approach. Studies illustrate that the smaller the population is, the more exaggerated the resource constraints and small state ecology become.

\section{Expanding the media and politics research agenda}

Many authors studying small states argue that more research on these states is required in different areas of examination. In my research on media and politics in Iceland (Ólafsson, 2019), I found that several aspects related to resource constraints and small state social ecology were relevant when analysing the relationship between politicians, journalists, and the public, as well as the dissemination of political information.

The possible influence of the size variable warrants further investigation if we want to gain a clearer understanding of media and politics in the Nordic region, as well as in media-related research more generally. I argue that it could be helpful to expand relevant research from academic fields that have focused on small states and size, and relate this work to the study of media and politics. Building 
on the work on the five traits of small states (Sarapuu, 2010) and research that has been carried out on small states in relation to the size variable - as well as my own work on political communication in Iceland (Ólafsson, 2019) - I propose the construction of frameworks that highlight four dimensions of "scaled down" political communication dynamics: offline network density, online network density, mobile multifunctionality, and flexible autonomy. These dimensions are not meant to be all-encompassing, but rather a useful roadmap for exploring avenues of further research. They outline assumptions in the existing literature before illustrating how the small state angle expands the research agenda.

The first dimension (offline network density) confronts the following assumption in much of the political communication literature on the national level: Media and political elites routinely operate in private spheres detached from the public. In political communication research, this separation is understood to influence the relationship between politicians and journalists and political news content. The politician-journalist relationship has often been examined in relation to private spheres such as Westminster or the Folketing in Denmark, both through individual case studies and in comparative studies (e.g., Davis, 2010; Van Aelst et al., 2010). The professional closeness between the two sides has raised various questions, such as how proximity in this setting possibly impairs journalists' independence.

I argue that this framework has limitations when examining politician-journalist relations in small states. In Iceland, for example, there is currently only one journalist based in the parliament; therefore, most of the daily working interactions between journalists and politicians do not take place there. But this does not mean that politicians and journalists are not close - they are, in fact, very close. In a small society, it is much more likely that you already know people you need to work with professionally, or that you know someone who knows that person.

So what does this mean for examining the relationship between journalists and politicians in small states? Instead of focusing on their intense professional interactions within institutional sites of power, we must expand how we conceptualise the relationship. It is not based mainly on professional closeness. Instead, the social closeness factor related to size shows that we need to examine how social proximity, as well as proximity to the public, affects their relationship. This is a key difference from the studies on politican-journalist relations in larger states, including the other Nordic states (e.g., Dindler, 2015), where the public is routinely ignored when examining politician-journalist relations.

The second dimension (online network density) moves the discussion to underlying assumptions in the ever-expanding literature concerning online political communication interactions. Much of the existing work shows the following: Politicians mainly engage in one-way digital broadcast style communication, and there is limited engagement with citizens online (e.g., Jungherr, 2016). I argue that an underlying assumption guides much of this work: There is a level of distance between politicians and citizens offline, which is replicated in the online communication ecology. 
Debates concerning the democratic potential of the internet are often discussed in terms of techno-optimism and techno-pessimism. On the optimist side, much of the literature has focused on the internet's potential for breaking down barriers between politicians and citizens. The argument against the internet being an enhancer of democracy is commonly discussed in connection to societal inequalities. This can be related to the normalisation hypothesis, which focuses on how relationship patterns online resemble those of the real world (e.g., KocMichalska et al., 2016). What most of the empirical studies on politicians' behaviour on social media reveal is that they interact infrequently with other users. Politicians mainly replicate existing messages and campaign modes online and engage in a very limited way with users (e.g., Stier et al., 2018). This suggests a much stronger case for the normalisation hypothesis as opposed to the democracyenhancing two-way interaction argument.

There is a key limitation in this research which is linked to the exclusion of small states. Their inclusion would expand the normalisation argument and the framework of study. As outlined, there is much more closeness between elites and citizens in small states. The real story of small state politics concerns informal dynamics in a range of settings (Corbett \& Veenendaal, 2018). If we follow the normalisation argument, one should therefore find similar sorts of dynamics when examining online interactions.

In Norway, it has been shown that local politicians participate more in twoway interaction with the public than politicians at the national level (Larsson $\&$ Skogerbø, 2018). Why might there be more interaction there? Could this be related to the size variable? If we are to include smaller states in future comparative research on the national level, we must be aware of the possibility that citizens in these states might expect a response from national level politicians online, as my research suggests (Ólafsson, 2019). The inclusion of small states could therefore substantially enrich this area of research.

The third dimension (mobile multifunctionality) confronts the following underlying assumption: The degree of specialisation can allow political journalists to work mainly on stories related to politics. When examining the literature on the politician-journalist relationship, it quickly becomes apparent that political journalist is assumed to be a useful term for comparative analysis across states. This is routinely discussed with regard to journalists who work in national parliaments, including in the Nordic countries (e.g., Albæk et al., 2014).

Most journalists and politicians in small states need to be multifunctional generalists, rather than specialists in specific areas - the term political journalist therefore does not make sense in this setting. Multi-functionalism is also required in larger states, but existing research suggests that it becomes more exaggerated in small states (Randma-Liiv \& Sarapuu, 2019). My research shows that resource constraints seriously impair Icelandic journalists' possibilities for in-depth reporting on politics. This was seen by many journalists to give more power to politicians and was perceived to limit the possibility for the media to be a watchdog. 
What was, however, also apparent is that politicians are grappling with resource constraints, and this can limit their dominance (Ólafsson, 2019).

Working conditions in small states can contribute to thin and superficial knowledge in the political sphere. Resource constraints and the lack of specialisation can create a vacuum that can be filled by "outside" voices. It is difficult for journalists to be critical gatekeepers if they know little about the areas in which they work. Future research should examine the news outputs in relation to these working conditions and show an awareness for how outsiders can influence the news coverage. This leads to the final dimension (flexible autonomy), which concerns the roles and responsibilities of individuals in small states.

In existing national-level political communication research, the unit of analysis is often something that exists "above" the individual, such as the media outlet and political party (e.g., Stroud \& Lee, 2013; Strömback \& Kaid, 2008). The focus is therefore not on the individuals as such, but rather on the units in which they operate. These units can be perceived as some sort of explanatory variable regarding the individuals' behaviour. There appears, therefore, to be an underlying assumption in some of this literature in that the professional roles journalists and politicians play can, at least to a degree, be studied without taking into account the actual individuals who take on these roles. In other words, the professional roles exist first, and then certain people fill these roles in relation to pre-existing norms of behaviour. When examining roles played by individuals in small states, there is a need to frame this somewhat differently.

My work has shown that Icelandic politicians and journalists have much room to manoeuvre in their everyday working practices, and they often lack guidance and support (Ólafsson, 2019). This is similar to previous findings from public administration research. Small state administrations tend to rely more on flexibility and informal means of communication (Raadschelders, 1992). When many intervening management levels are missing, problematic issues will quickly reach the top of the administration. There is, therefore, an incentive built into the small systems to trust individual officials and units (Sarapuu, 2010). This seems to be the case in the media and political spheres in Iceland.

What this flexible autonomy suggests is that individuals working outside of hierarchical structures play a key role in political communication dynamics. This leads to the realisation that when examining small states, it is important to study individuals themselves much more closely than usually done in much of the research on larger states. This can be related back to the discussion in the network density dimensions. People in small states interact over and over again, in all sorts of situations, which can lead to more particularistic identities and can be contrasted to the more universalistic Weberian work identities in larger states. 


\section{Conclusion}

The world's smallest states are routinely ignored in media-related research. The same applies, to an extent, to small states in other academic fields, such as political science and public administration. The scarce work that has been conducted in those fields has revealed an important finding: small states have a lot in common. And, moreover, these commonalities draw attention to certain differences when compared to larger states. Studies show that small states cannot simply be viewed as smaller versions of the large states that have been central in knowledge production. The differences related to size are not solely quantitative. They are, importantly, also qualitative (Randma-Liiv \& Sarapuu, 2019).

Blumler and Gurevitch (1995) point out the problem of naïve universalism, the tendency to presume that findings from one country are universal. It is clear from my work on Iceland (Ólafsson, 2019) that the heavy reliance on research from large- and medium-sized democracies has resulted in underlying assumptions in the political communication discipline that are not applicable when examining the Icelandic case. Existing frameworks do not capture important elements in the media and politics ecology in a small state like Iceland. This is partly due to previous research not engaging systematically with size as a variable when examining political communication dynamics at the national level. This does not become apparent until one starts to include small states in the mix of states studied, since the clearest difference in the impact of the size variable should, logically, be between the largest and smallest states. I strongly encourage researchers to include Iceland in their future studies on the Nordic region. ${ }^{2}$ This will enrich our understanding of the Nordic countries and also open up new areas of study on small and large states more generally.

\section{Notes}

1. There are of course exceptions (see, e.g., Lowe \& Nissen, 2011, concerning television broadcasting in small countries, and Trappel, 1991, 2014, concerning media policy and small states).

2. Aside from the size issue, recent research has shown how Iceland differs from the other Nordic states in numerous ways when it comes to its political and media systems (cf. Jóhannsdóttir \& Ólafsson, 2018).

\section{References}

Albæk, E., Van Dalen, A., Jebril, N., \& de Vreese C. (2014). Political journalism in comparative perspective. Cambridge: Cambridge University Press. https://doi.org/10.1017/CBO9781139567367

Blumler, J. G., \& Gurevitch, M. (1995). The crisis of public communication. New York: Routledge. https://doi.org/10.4324/9780203181775

Bray, M., \& Packer, S. (2006). Education in small states: Concepts, challenges and strategies. Oxford: Pergamon Press.

Central Intelligence Agency. (2020). The World Factbook. Retrieved March 8, 2020, from https:// www.cia.gov/library/publications/the-world-factbook/

Corbett, J., \& Veenendaal, W. (2018). Democracy in small states: Persisting against all odds. Oxford: Oxford University Press. https://www.doi.org/10.1093/oso/9780198796718.001.0001

Davis, A. (2010). Political communication and social theory. New York: Routledge. https://doi. org/10.4324/9780203847299 
de Vreese, C. (2017). Comparative political communication research. In K. Kenski, \& K. Hall Jamieson (Eds.), The Oxford handbook of political communication. Oxford: Oxford University Press. https://www.doi.org/10.1093/oxfordhb/9780199793471.013.82

Dindler, C. (2015). Negotiating political news: The two phases of off-the-record interaction. Journalism, 16(8), 1124-1140. https://doi.org/10.1177/1464884914555963

Dobek-Ostrowska, B., Jakubowicz, K., Sükösd, M., \& Głowacki, M. (2010). Comparative media systems: European and global perspectives. Budapest: Central European University Press.

Farrugia, C. (1993). The special working environments of senior administrators in small states. World Development, 21(2), 221-226. https://doi.org/10.1016/0305-750X(93)90017-4

Hallin, D. C., \& Mancini, P. (2004). Comparing media systems: Three models of media and politics. Cambridge: Cambridge University Press. https://doi.org/10.1017/CBO9780511790867

Ingebritsen, C., Neumann, I., Gstöhl, S., \& Beyer, J. (Eds.). (2006). Small states in international relations. Seattle: University of Washington Press/University of Iceland Press.

Jóhannsdóttir, V., \& Ólafsson, J. G. (2018). The Icelandic news media in times of crisis and change. Icelandic Review of Politics \& Administration, 14(1), 189-210. https://doi.org/10.13177/ irpa.a.2018.14.1.9

Jungherr, A. (2016). Twitter use in election campaigns: A systematic literature review. Journal of Information Technology and Politics, 13(1), 72-91. https://doi.org/10.1080/19331681.2015.1132401

Koc-Michalska, K., Lilleker, D. G., Smith, A., \& Weissman, D. (2016). The normalization of online campaigning in the web.2.0 era. European Journal of Communication, 31(3), 331-350. https:// doi.org/10.1177/0267323116647236

Larsson, A. O., \& Skogerbø, E. (2018). Out with the old, in with the new? Perceptions of social (and other) media by local and regional Norwegian politicians. New Media \& Society, 20(1), 219-236. https://doi.org/10.1177/1461444816661549

Lowe, G. F., \& Nissen, C. S. (Eds.). (2011). Small among giants: Television broadcasting in smaller countries. Gothenburg: Nordicom, University of Gothenburg.

Ólafsson, J. G. (2019). Media, democracy and small states: Political communication in Iceland. [Doctoral thesis, Goldsmiths, University of London]. https://doi.org/10.25602/GOLD.00026852

Puppis, M. (2009). Media regulation in small states. International Communication Gazette, 71(1-2), 7-17. https://doi.org/10.1177/1748048508097927

Raadschelders, J. B. (1992). Definitions of smallness: A comparative study. In R. Baker (Ed.), Public administration in small and island states (pp. 27-32). West Hartford, Connecticut: Kumarian Press.

Randma, T. (2001). A small civil service in transition: The case of Estonia. Public Administration and Development, 21(1), 41-51. https://doi.org/10.1002/pad.153

Raandma-Liiv, T. (2002). Small states and bureaucracy: Challenges for public administration. Trames, 6(4), 374-389.

Randma-Liiv, T., \& Sarapuu, K. (2019). Public governance in small states: From paradoxes to research agenda. In A. Massey (Ed.), A research agenda for public administration (pp. 162-179). Cheltenham, UK: Edward Elgar Publishing.

Sarapuu, K. (2010). Comparative analysis of state administrations: The size of state as an independent variable. Halduskultuur, 11(1), 30-43.

Statistics Iceland. (2020). The population increased by 1,400 in the fourth quarter of 2019 . Retrieved March 8, 2020, from https://www.statice.is/publications/news-archive/inhabitants/populationin-the-4th-quarter-2019/

Stier, S., Bleier, A., \& Lietz, H. (2018). Election campaigning on social media: Politicians, audiences, and the mediation of political communication on Facebook and Twitter. Political Communication, 35(1), 50-74. https://doi.org/10.1080/10584609.2017.1334728

Stroud, N. J., \& Lee, J. K. (2013). Perceptions of cable news credibility. Mass Communication and Society, 16(1), 67-88. https://doi.org/10.1080/15205436.2011.646449

Strömback, J., \& Kaid, L. L. (Eds.). (2008). The handbook of election news coverage around the world. New York: Routledge. https://doi.org/10.4324/9780203887172

Thorhallsson, B., \& Steinsson, S. (2017). Small state foreign policy. Oxford research encyclopedia of politics. Oxford University Press. https://doi.org/10.1093/acrefore/9780190228637.013.484

Trappel, J. (1991). Born losers or flexible adjustment? The media policy dilemma of small states. European Journal of Communication, 6(3), 355-371. https://doi.org/10.1177/0267323191006003006

Trappel, J. (2014). Small states and European media policy. In K. Donders, C. Pauwels, \& J. Loisen (Eds.), The Palgrave handbook of European media policy (pp. 239-253). London: Palgrave Macmillan. https:www.doi.org/10.1057/9781137032195 
Van Aelst, P., Sehata, A., \& Van Dalen, A. (2010). Members of parliament: Equal competitors for media attention? An analysis of personal contacts between MPs and political journalists in five European countries. Political Communication, 27(3), 310-325. https://doi.org/10.1080/10584 609.2010.496711

Van Dalen, A., \& Van Aelst, P. (2014). The media as political agenda-setters: Journalists' perceptions of media power in eight west European countries. West European Politics, 37(1), 42-64. https:// doi.org/10.1080/01402382.2013.814967

Veenendaal, W. P., \& Corbett, J. (2015). Why small states offer important answers to large questions. Comparative Political Studies, 48(4), 527-549. https://doi.org/10.1177/0010414014554687

Copyright: (C) 2020 The Author(s) and Nordicom. This is an Open Access article distributed under the terms of the Creative Commons Attribution 4.0 International License (CC BY-NC-ND 4.0). 